\title{
HYGIENIC ASSESSMENT OF HANDICAPPED ADOLESCENTS VOCATIONAL TRAINING CONDITIONS: PROBLEMS AND OPTIMIZATION OPPORTUNITIES
}

\author{
Eliseeva YuV ${ }^{1 凶}$, Voytovich $A^{1}{ }^{1}$, Milushkina OYu², Istomin AV, Eliseev YuYu ${ }^{1}$ \\ ' General Hygiene and Ecology Department, Razumovsky Saratov State Medical University, Saratov \\ ${ }^{2}$ Hygiene Department, Pirogov Russian National Research Medical University, Moscow \\ ${ }^{3}$ Healthy and Safe Nutrition Department, Institute for Complex Hygiene Problems, Erisman Federal Research Center for Hygiene, Moscow
}

In a number of occupations, there is a shortage of labor force that can be filled with economically active part of the population, including people with disabilities (handicapped, HC). Unfortunately, observance of hygienic requirements in the context of HP adolescents vocational training has not been studied sufficiently: most scholars have researched only the conditions of teaching healthy adolescents. This study aimed to examine the HC adolescents vocational training conditions and develop measures to improve their working conditions with pathologies factored in. We examined adaptation potential, anxiety level, mental efficiency, sick rate and personal well-being assessment in HC adolescents $(n=120)$ aged $16-18$, not impaired intellectually, studying sewing equipment operation, shoe repairs in the boarding scool. In the context of the study, we applied Smirnov hygiene criteria, Giessen Symptom Questionnaire, Spielberger's Test Anxiety Questionnaire, Sivkov scale, correction tables, Baevsky adaptation index. For the purposes of statistical analysis, we used parametric (Student $t$-test) and nonparametric (Mann-Whitney) criteria. The Spearman's correlation coefficient helped determine interrelationship of the studied parameters. We identified the following key adverse hygienic factors that have a significant impact on the students' health: intense character of labor performed, insufficient artificial lighting, noise level above the norm, high content of organic solvents and dust in the workshop's air. The timetable of the boarding school was also found to be inefficient. The results of this study allowed developing and introducing a software program to automatically compile the school's timetable with the aim to improve psychosomatic health of the students and halve the number of health-related complaints.

Keywords: handicapped students, vocational training, training and production environment factors, adaptation, classes timetable

$\triangle$ Correspondence should be addressed: Yulia V. Eliseeva

B. Kazachya 112, Saratov, 410012; eliseeva-gig@mail.ru

Received: 17.06.2018 Accepted: 16.11 .2018

DOI: $10.24075 / \mathrm{brsmu} .2018 .060$

\section{ГИГИЕНИЧЕСКАЯ ОЦЕНКА УСЛОВИЙ ПРОФЕССИОНАЛЬНОГО ОБУЧЕНИЯ ПОДРОСТКОВ С ОГРАНИЧЕННЫМИ ВОЗМОЖНОСТЯМИ: ПРОБЛЕМЫ И ПУТИ ОПТИМИЗАЦИИ}

\author{
Ю. В. Елисеева ${ }^{1 凶}$, А. А. Войтович ${ }^{1}$, О. Ю. Милушкина², А. В. Истомин ${ }^{3}$, Ю. Ю. Елисеев ${ }^{1}$
}

${ }^{1}$ Кафедра общей гигиены и экологии, Саратовский государственный медицинский университет имени В. И. Разумовского, Саратов

${ }^{2}$ Кафедра гигиены, Российский национальный исследовательский медицинский университет имени Н. И. Пирогова, Москва

${ }^{3}$ Отдел здорового и безопасного питания, Институт комплексных проблем гигиены, Федеральный научный центр гигиены имени Ф. Ф. Эрисмана, Москва

Для восполнения недостатка трудовых кадров по ряду профессий представляется возможным использование экономически активной части населения страны, в том числе лиц с ограниченными возможностями (ОВ). К сожалению, соблюдение гигиенических требований в ходе профессионального обучения подростков с ОВ недостаточно изучено, поскольку в основном имеются данные об исследованиях условий подготовки только здоровых подростков. Целью работы были изучение условий профессионального обучения подростков с ОВ, разработка мероприятий по улучшению условий их труда с учетом имеющейся патологии. Подростки с ОВ (120 человек) в возрасте 16-18 лет с сохраненным интеллектом, обучающиеся в интернате по специальностям оператор швейного оборудования, обувщик по ремонту обуви, обследованы по показателям адаптационного потенциала, тревожности, умственной работоспособности, а также заболеваемости и субъективной оценке самочувствия. Использовали гигиенические критерии Смирнова, анкетирование с помощью Гиссенского опросника, тест Спилбергера, шкалу Сивкова, корректурные таблицы, методику Баевского. Для статистического анализа применены параметрический ( $t$-критерий Стьюдента) и непараметрический (Манна-Уитни) критерии. Связь изучаемых параметров определена по коэффициенту корреляции Спирмена. Выявлены ведущие неблагоприятные гигиенические факторы, оказывающие значимое влияние на организм учащихся: тяжесть и напряженность трудового процесса, недостаточный уровень искусственной освещенности, превышение уровня шума, высокое содержание органических растворителей и уровня пыли в воздухе рабочей зоны. Определено нерационально составленное расписание учебных занятий в интернате. Результаты исследования позволили разработать и внедрить компьютерную программу автоматизированного составления расписания, позволяющую улучшить психосоматическое состояние здоровья и вдвое снизить количество жалоб на самочувствие.

Ключевые слова: учащиеся с ограниченными возможностями, просессиональное обучение, факторы учебнопроизводственной среды, адаптация, расписание занятий

$\triangle$ Для корреспонденции: Юлия Викторовна Елисеева ул. Б. Казачья, д. 112, г. Саратов, 410012; eliseeva-gig@mail.ru

Статья получена: 17.06.2018 Статья принята к печати: 16.11 .2018

DOI: $10.24075 /$ vrgmu.2018.060 
Preserving and strengthening health of adolescents is a topical problem nowadays and the most important task before the state $[1,2]$. Overall, the state of health of children and adolescents worsens, which translates into the growing number of acknowledged disabilities that put health-related restrictions on the access to vocational education [3-6]. The law "On Social Protection of Disabled Persons in the Russian Federation", adopted in 1995, guarantees social protection for people with disabilities, as well as unrestricted access to education. However, execution of $\mathrm{HC}$ adolescents vocational training is significantly limited. Moreover, training and production environment factors influence health of students learning various trades [7-10]. At the earliest stages, the influence manifests as disorders of adaptation mechanisms accompanied by morphofunctional disorders; these are the first signals of changes in health of students associated with vocational training $[11,12]$. To make the training more effective, it is necessary to know how persons with disabilities adapt to the conditions this training occurs in. Thus, studying the $\mathrm{HC}$ adolescents' ability to adapt to learning trades in secondary vocational schools, the specifics considered, is a task of practical significance.

This study aimed to examine the conditions $\mathrm{HC}$ adolescents receive vocational education in and develop measures aiding their adaptation to training and production environment factors.

\section{METHODS}

The study was conducted at the Saratov Vocational Boarding School for Handicapped and Disabled Persons (State Autonomous Vocational Education Institution) in 2016-2017; it was approved by the Ethics Committee of V. I. Razumovsky State Medical University, city of Saratov (Protocol \#3 of 07.11.2017). As prescribed by the Federal Law \#323-FZ of 21.11.2011 "On the Principles of Protection of Health of Citizens in the Russian Federation" (revision of 03.07.2016), all participants gave the informed voluntary consent to the research activities; under Article 9 of the Federal Law \#152-FZ of 27.07.2006 "On Personal Data", they agreed to have their personal data processed.

We studied the training and production environment factors that affect adaptation of students. The study group included $120 \mathrm{HC}$ adolescents aged 16 to 18; $58 \%$ of them had I-III class disabilities. Inclusion criteria: learning "sewing equipment operator", "shoe repairman" trades in the boarding school; lack mental impairments. Exclusion criteria: severe mental disorders; low intelligence; proneness to conflict.

The training and production processes organization was studied through examining the chronometry (time and sequence of specific operations registered by seconds). Hygienic criteria suggested by N. K. Smirnov [13] enabled evaluation of the rationality of theoretical and practical classes; daily study load calculations helped estimate the soundness of weekly and daily load distribution pattern [14]. Form 086/u (approved by the Ministry of Health of the Russian Federation on 08.12.2014) provided the objective data describing state of the students' health. Analysis of the personal rehabilitation program forms (approved by Order \#379n of 04.08.2008 issued by the Ministry of Health and Social Development of Russia) allowed studying the reasons and structures of the students' disabilities. We referred to classes and nosological entities described in ICD10 when examining levels and structures of the diseases.

Giessen Symptom Questionnaire allowed the students to express their own view of the state of their health [15].
State-Trait Anxiety Inventory (Spielberger test) [16] enabled expression of personal and situational anxiety by the adolescents.

Baevsky adaptation index (as modified by A. P. Berseneva in 1995) [17] allowed calculating adaptation indices in the context of the personal adaptation capabilities assessment.

Correction tables by V. Ya. Anfimov (as modified by S. M. Grombakh) [18] were used to assess mental efficiency of the students.

Various criteria (Student $t$-test, Mann-Whitney test, means difference significance $p$ ) were used to establish significance of differences in the parameters studied. We considered the differences found significant at $p<0.05 ; p<0.01 ; p<0.001$; the minimal significance level was 95\%. Spearman's rank correlation coefficient $(r)$ was used to determine closeness and significance of the relationship between the parameters. The data obtained was processed with the help of MS Excel Statistica 6.0 software.

\section{RESULTS}

\section{Shoe repairman vocational training conditions evaluation}

The labor component of the shoe repairman vocational education, as it is given to $\mathrm{HC}$ adolescents, is a heavy burden in itself: over $80 \%$ of the practical class implies sitting down in an awkward position forced by the specifics of operations performed. Artificial lighting of the workbenches was insufficient: in the training workshops, light intensity at the working surface of the benches was $226.5 \pm 13.8 \mathrm{~lx}$, while the norm is $300 \mathrm{~lx}$. The air inside the students' working area contained excessive volumes of specific substances: acetone (up to 4.5 times the maximum allowable concentration), carbon dioxide (up to 1.5 times the maximum allowable concentration). As for the moderately hazardous industrial allergens (rosin, formaldehyde), their shift-average concentrations did not exceed the allowable levels. Taking into account the detected concentrations of chemicals in the working area air, the labor conditions of $\mathrm{HC}$ adolescents should be considered harmful. Moreover, examination of the educational process revealed irrationalities in length and sequence of various activities associated with the shoe repairman vocational training.

\section{Sewing equipment operator vocational training conditions evaluation}

Examining the conditions adolescents learn to operate sewing equipment in from the point of view of hygiene, we learned a number of factors affecting them:

1) labor intensity - working operations, which make up $82 \%$ of the lesson's duration, require a forced posture (sitting, body leaning forward)

2) strain - over $40 \%$ of the lesson the students had to concentrate on a single object;

3) lighting - the artificial illumination level registered in the context of using the sewing equipment was only $1456.2 \pm 24.1 \mathrm{~lx}$, while the norm is $2000 \mathrm{~lx}, p=0.15$; at ironing workbenches and manual operations desks the level was $350.7 \pm 13.7 \mathrm{~lx}$, while the norm is $600 \mathrm{~lx}, p=0.03$;

4) noise - during manual operations and ironing the sound pressure level in the workshop was $82.4 \pm 2.4 \mathrm{~dB}$; we have registered the excess of $9.5 \pm 3.2 \mathrm{~dB}$ in the frequency range from 500 to $8000 \mathrm{~Hz}$; in total, the students suffered from excessive noise $54.3 \%$ of time in class; the noise level reached $82.4 \pm 2.4 \mathrm{~dB}$, which exceeded the permissible values by $2 \mathrm{~dB}$. 
We connected the results obtained with improper organization of workplaces in the workshop: manual operations, ironing and sewing equipment zones were next to each other and in the single room. Sewing machine produced noise to the level of $87.1 \pm 2.1 \mathrm{~dB}$, while the chain weave machine's sound pressure level was $85.2 \pm 3.5 \mathrm{~dB}$. Both are in excess of the maximum permissible level of $80 \mathrm{~dB}$.

\section{Students sick rate assessment}

In the first half of the school year, the sick rate was 5.23 cases per 1000 people (calculated from the registered visits to doctors). In the second half, the rate was greater than in the first (difference statistically significant, $p<0.01$ ): 7.08 cases per 1000 students. The pathology index in the group was $199.5 \pm 16.7$ per 100 people. The most common disorders were those of the neuropsychic sphere (43.8\%), musculoskeletal system (18.3\%), circulatory system (16.5\%).

\section{Students working efficiency evaluation}

We tested the students mental efficiency (ME) at the beginning and at the end of several lessons to cover all the subjects studied (Table 1). According to the integral assessment, more than half of the adolescents (64.2 $\pm 3.1 \%)$ exhibited low levels of $\mathrm{MC}$ at the beginning of classes; only $14.2 \pm 2.1 \%$ of students showed high $\mathrm{MC}$. At the end of the class, there were more people with high $\mathrm{MC}(35.4 \pm 3.3 \%)$ while the number of those who still remained at the low ME level decreased to $25.8 \pm 0.9 \%$. The dynamics revealed result from the longer warm-up period, which is one of the functioning peculiarities of CNS of $\mathrm{HC}$ adolescents.

We applied the method suggested by P. V. Nefedov, N. B. Kutumova [14] when distributing the HC students according to their $\mathrm{ME}$ based on the data obtained through the week. The ME levels were determined with the daily study load coefficient taken into account (Table 2). On Mondays, the students' performance in studying was low, which may have been the result of changes in their daily routine (most of them left for home on Saturday and returned to the boarding school on Monday morning). The efficiency upturned sharply on Tuesday and Wednesday, then decreased gradually Thursday through Saturday, which indicates the predominance of inhibition processes in CNS as a result of accumulating fatigue.

A more detailed analysis of the efficiency levels demonstrated by $\mathrm{HC}$ adolescents through the school day

Table 1. Examination of mental efficiency of HC adolescents with the help of correction tables by V. Ya. Anfimov (as modified by S. M. Grombakh)

\begin{tabular}{|c|c|c|c|c|c|c|c|c|c|c|c|c|}
\hline \multirow{2}{*}{$\begin{array}{l}\text { Subjects } \\
\text { studied }\end{array}$} & \multicolumn{2}{|c|}{ Number of letters viewed } & \multirow{2}{*}{$\begin{array}{c}\text { Student } \\
t \text {-test }\end{array}$} & \multirow{2}{*}{$p$} & \multicolumn{2}{|c|}{$\begin{array}{l}\text { Average number } \\
\text { of errors per } 500 \\
\text { characters }\end{array}$} & \multirow{2}{*}{$\begin{array}{c}\text { Student } \\
t \text {-test }\end{array}$} & \multirow{2}{*}{$p$} & \multicolumn{2}{|c|}{$\begin{array}{l}\text { Task performance } \\
\text { accuracy (\%) }\end{array}$} & \multicolumn{2}{|c|}{ Performance } \\
\hline & $\begin{array}{l}\text { Start } \\
\text { of class }\end{array}$ & $\begin{array}{l}\text { End } \\
\text { of class }\end{array}$ & & & $\begin{array}{l}\text { Start } \\
\text { of class }\end{array}$ & $\begin{array}{l}\text { End } \\
\text { of class }\end{array}$ & & & $\begin{array}{l}\text { Start } \\
\text { of class }\end{array}$ & $\begin{array}{l}\text { End } \\
\text { of class }\end{array}$ & $\begin{array}{l}\text { Start } \\
\text { of class }\end{array}$ & $\begin{array}{l}\text { End } \\
\text { of class }\end{array}$ \\
\hline $\begin{array}{l}\text { Professional } \\
\text { occupation }\end{array}$ & $445.2 \pm 9.1$ & $479.3 \pm 11.4$ & 2.39 & 0.004 & $53.9 \pm 2.7$ & $49.9 \pm 1.8$ & 1.23 & 0.0001 & $89.1 \pm 3.2$ & $90.7 \pm 2.4$ & $4.9 \pm 0.2$ & $5.2 \pm 0.5$ \\
\hline $\begin{array}{l}\text { Production } \\
\text { technology }\end{array}$ & $580.4 \pm 10.5$ & $452.1 \pm 8.7$ & 10 & 0.019 & $50.9 \pm 1.3$ & $73.0 \pm 4.1$ & 5.14 & 0.001 & $91.9 \pm 1.5$ & $86.0 \pm 1.9$ & $6.3 \pm 0.9$ & $5.2 \pm 0.1$ \\
\hline Equipment & $544.3 \pm 9.1$ & $425.2 \pm 7.6$ & 10.44 & 0.017 & $49.8 \pm 2.7$ & $71.4 \pm 3.6$ & 4.8 & 0.001 & $91.6 \pm 2.1$ & $85.6 \pm 1.1$ & $5.9 \pm 1.0$ & $5.2 \pm 0.3$ \\
\hline $\begin{array}{l}\text { Materials } \\
\text { Science }\end{array}$ & $520.4 \pm 9.7$ & $429.4 \pm 7.2$ & 7.98 & 0.013 & $53.1 \pm 3.1$ & $70.6 \pm 2.3$ & 4.53 & 0.0009 & $94.0 \pm 1.8$ & $85.8 \pm 2.9$ & $5.5 \pm 1.2$ & $5.0 \pm 0.4$ \\
\hline $\begin{array}{l}\text { Industry and } \\
\text { enterprise } \\
\text { economics }\end{array}$ & $600.4 \pm 9.1$ & $512.8 \pm 8.6$ & 7.31 & 0.013 & $56.6 \pm 1.5$ & $70.5 \pm 1.3$ & 5.06 & 0.0007 & $91.3 \pm 2.2$ & $87.8 \pm 2.6$ & $6.3 \pm 0.9$ & $5.8 \pm 0.8$ \\
\hline $\begin{array}{l}\text { Fundamentals } \\
\text { of artistic } \\
\text { design }\end{array}$ & $519.3 \pm 8.6$ & $459.3 \pm 7.7$ & 5.64 & 0.008 & $58.9 \pm 1.6$ & $67.1 \pm 1.8$ & 3.4 & 0.0004 & $88.5 \pm 1.7$ & $87.2 \pm 2.9$ & $5.8 \pm 0.8$ & $5.2 \pm 1.1$ \\
\hline $\begin{array}{l}\text { Special } \\
\text { drawing }\end{array}$ & $587.1 \pm 9.5$ & $536.2 \pm 8.1$ & 4.24 & 0.008 & $52.1 \pm 1.4$ & $56.3 \pm 1.4$ & 2.2 & 0.0002 & $91.8 \pm 1.5$ & $90.4 \pm 3.1$ & $6.3 \pm 0.3$ & $5.9 \pm 0.2$ \\
\hline $\begin{array}{l}\text { Native region } \\
\text { history }\end{array}$ & $603.8 \pm 20.2$ & $551.6 \pm 8.4$ & 2.41 & 0.008 & $54.7 \pm 3.1$ & $59.1 \pm 1.6$ & 1.26 & 0.0002 & $91.6 \pm 3.2$ & $90.3 \pm 2.9$ & $6.5 \pm 0.2$ & $6.1 \pm 0.2$ \\
\hline $\begin{array}{l}\text { Ethics and } \\
\text { culture of } \\
\text { communication }\end{array}$ & $498.7 \pm 16.5$ & $455.3 \pm 7.5$ & 2.46 & 0.022 & $56.8 \pm 1.9$ & $61.4 \pm 1.5$ & 1.9 & 0.0002 & $89.7 \pm 1.9$ & $88.1 \pm 2.1$ & 5.5 & 5.1 \\
\hline $\begin{array}{l}\text { Basics of } \\
\text { life safety }\end{array}$ & $401.6 \pm 6.9$ & $463.6 \pm 8.1$ & 6.2 & 0.008 & $55.2 \pm 2.4$ & $49.8 \pm 1.8$ & 1.8 & 0.0002 & $87.9 \pm 2.6$ & $90.2 \pm 3.5$ & 4.9 & 5.1 \\
\hline $\begin{array}{l}\text { Occupational } \\
\text { safety }\end{array}$ & $401.8 \pm 5.4$ & $445.3 \pm 2.1$ & 8.17 & 0.006 & $59.7 \pm 2.4$ & $54.3 \pm 1.3$ & 1.98 & 0.0002 & $87.0 \pm 2.4$ & $89.1 \pm 4.0$ & 4.6 & 5.1 \\
\hline $\begin{array}{l}\text { Adaptive } \\
\text { physical culture }\end{array}$ & $481.1 \pm 4.4$ & $571.2 \pm 9.1$ & 9.14 & 0.013 & $54.1 \pm 1.3$ & $43.4 \pm 5.4$ & 1.93 & 0.0005 & $89.8 \pm 2.8$ & $92.9 \pm 1.3$ & 5.3 & 6.1 \\
\hline
\end{tabular}

Table 2. Efficiency of students through the week

\begin{tabular}{|c|c|c|c|}
\hline Days of week & Number of letters viewed & The total number of characters in the test & Load coefficient value (\%) \\
\hline Monday & $121 \pm 5.2$ & \multirow{6}{*}{868} & 14 \\
\hline Tuesday & $170 \pm 1.9$ & & 19.7 \\
\hline Wednesday & $171 \pm 0.9$ & & 19.7 \\
\hline Thursday & $149 \pm 2.5$ & & 17.2 \\
\hline Friday & $133 \pm 1.3$ & & 15.4 \\
\hline Saturday & $120 \pm 6.2$ & & 14 \\
\hline
\end{tabular}


revealed some differences from the classical daily performance curve. The efficiency level was at its highest on the 3-rd or 4-th hour of work, then it dropped, and the drop was followed by the final burst that has the performance peaking; compared to the classic efficiency level curve, the burst was shifted for 2-3 hours.

\section{Assessment of adaptation capabilities}

Assessing the students' adaptation capabilities, we learned that the adaptation index (Al) of $39.3 \pm 1.1 \%$ of young men was 8.25 to 9.86 , which corresponds to the unsatisfactory level of adaptation. As for the young women, $34.5 \pm 1.6 \%$ of them had the adaptation index at unsatisfactory levels, and $26.5 \pm 0.7 \%$ have exhibited signs of stressed adaptation mechanisms.

There were $26.3 \%$ more girls with satisfactory adaptation levels than boys. Increasing Al may signal of the health deterioration trend associated with decreased efficiency and growing fatigue.

It was found that adaptation of $48.1 \%$ of non-HC adolescents was unsatisfactory, while that of $\mathrm{HC}$ students was $41.6 \%$.

As for the anxiety, the assessment revealed the average level of state anxiety to be low and that of trait anxiety moderate in the adolescents. Among the participating HC students, $76.2 \%$ exhibited low state anxiety values ( $<30$ points), which indicates that they are depressed, areactive and unmotivated to study. $23.8 \%$ of the students showed moderate state anxiety levels (33-44 points). A considerable share of adolescents (51.3\%) studying to operate sewing equipment exhibited high trait anxiety, $52 \pm 1.4$ points; this is the result of their proneness to perceive a wide range of life situations as threatening and respond to them with a pronounced reaction. The trend reflected the peculiarities of personal patterns found in this group.
Correlation analysis allowed establishing that life in the dormitory is a positive example of successful adaptation of $\mathrm{HC}$ adolescents to the microenvironment of vocational education institution ( $r=0.32$ ). Besides, we have found the Al to be moderately associated with the trait anxiety level ( $r=0.36)$, which characterizes peculiarities of personal patterns and those of body functioning under stress. Thus, adolescents with lower stress levels were able to adapt to the vocational training conditions in an educational institution better. State anxiety and Al were found to be inversely associated with each other, the association being moderate $(r=-0.38)$. Those students whose motivation to study was low showed unsatisfactory adaptation values.

\section{Classes timetable assessment}

Vocational training implies greater studying-related loads, since the curriculum has special subjects (technology, materials science, vocational training etc.) added to it. Thus, one of the major challenges in educating $\mathrm{HC}$ adolescents when they start learning a trade is to compile the timetable in a rational manner.

The ranked subject difficulty scale developed by I. G. Sivkov [18] is one of the methods used to evaluate the timetable from the point of view of hygiene. However, in case of a vocational school this scale is inapplicable since it contains no specific profession-related subjects.

We assessed the difficulty of the curriculum subjects through monitoring functions of the students' CNS (ME indicators, correction tables). Analysis of dynamics of the CNS functions' indicators revealed certain trends governing changes in the parameters studied (Table 3).

Table 4 contains scores reflecting difficulty of the subjects as it was evaluated in the context of the research. We have compared this fatigue scale with the SanPiN 1186-03 Indicative Scale of Educational Subjects and found certain similarities

Table 3. Subjects scoring based on the dynamics of the students' CNS parameters

\begin{tabular}{|l|c|c|}
\hline \multicolumn{1}{|c|}{ Evaluation criteria } & Change in the number of viewed characters & Change in the number of errors \\
\hline Extremely low values (less than $M-2 \sigma)$ & $-27.0-18.1 \%$ & $+27.0+18.1 \%$ \\
\hline Low values $(M-2 \sigma)$ & $-18.0-9.1 \%$ & $+18.0+9.1 \%$ \\
\hline Below average $(M-1 \sigma)$ & $-9.0-0 \%$ & $+9.0+0 \%$ \\
\hline Average values $(M \pm 1 \sigma)$ & $+0+9.0 \%$ & $-0-9.1 \%$ \\
\hline Values above average $(M+2 \sigma)$ & $+9.1+18.0 \%$ & $-9.0-18.1 \%$ \\
\hline High values (more than $M+2 \sigma)$ & $+18.1+27.0 \%$ & 2 \\
\hline
\end{tabular}

Table 4. Subjects ability to cause fatigue, ranked scale

\begin{tabular}{|l|l|l|}
\hline \multicolumn{2}{|c|}{ Subject } & \multicolumn{2}{|c|}{ Sifficulty rank (points) } \\
\hline \multicolumn{2}{|c|}{} \\
\hline "Shoe technology", "Equipment", "Materials science for shoe production" & \multicolumn{1}{|c|}{ Sewing equipment operator profession } \\
\hline "Industry and enterprise economics", "Fundamentals of art design and shoe design" & 5 \\
\hline "Production training" & 3 \\
\hline "Occupational safety" & 2 \\
\hline "Physical culture" & 1 \\
\hline & 6 \\
\hline "Garments manufacturing technology", "Equipment", "Materials science" & \\
\hline "Design basics" & 5 \\
\hline "Special drawing", "Native region history", "Ethics and culture of communication" & \\
\hline "Production training" & 3 \\
\hline "Occupational safety", "Basics of life safety" & \\
\hline "Physical culture" & 1 \\
\hline
\end{tabular}


between the two. Thus, it was deemed possible to equate the compiled fatigue scale to the difficulty scale and call it accordingly.

Hygienic assessment of the sewing equipment operator curriculum timetable showed that the study load therein is not distributed evenly: it grows gradual Monday to Wednesday, then drops unevenly Thursday to Saturday while peaking on Friday.

The curriculum timetable for the shoe repairmen profession was as unbalanced: maximum study load from Monday to Friday, no gradual growth or drop. We established that the timetable in both groups is not rational, which lead us to developing measures to adjust and optimize it.

\section{Application of the automated timetable compilation software}

Since compiling the classes timetable is a labor-intensive process, it was decided to automate it. For this purpose, a software program was developed and registered ("Automated Timetable Compilation Program for Primary Vocational Education Institutions", certificate 2016612429, state registration date 26.02.2016). The core of the system and its interface were coded in CSharp 2010, operating system type and version - Microsoft Visual Studio.

The software program we have developed distributes subjects through the weekdays based on their difficulty score in points. Its purpose is to compile a classes timetable that would agree with the weekly performance curve and the daily study load index peculiar to the HC students.

Application of the software starts with inputting name of the educational institution, name of the trade taught, curriculum year, group code. Names of the institution and trade are plain text, year and group code - numeric symbols.

Next, the user inputs the weekly amount of classroom hours of each subject. The subjects themselves are pre-defined in the software as they are listed in the basis curriculum.

Finally, the program automatically compiles timetables factoring in the subjects' difficulty scores.

The automated timetable compilation software allowed compiling a classes timetable that agrees with the basis hygiene requirements and principles of biorhythmology.

After 6 months with the new timetable, we have registered changes in the participants' ME: the number of adolescents whose ME was average before the classes has grown by $21.3 \%(p<0.05)$ and equaled $21.6 \pm 3.2 \%$. The number of adolescents whose efficiency was low decreased by $7.7 \%$ $(p>0.05)$ and equaled $59.2 \%$; the number of those with $\mathrm{ME}$ value above average has grown by $45.7 \%(p<0.05)$ and amounted to $5.1 \%$ of the total number of students.

At the end of the classes, the students' performance was better, too: the share of those demonstrating average and above average efficiency increased by $40 \%$ and $3.1 \%$, respectively $(p>0.05)$, while the number of students whose ME was below average dropped by $9.1 \%(p \leq 0,05)$.

Having analyzed the students' psychosomatic complaints again, we discovered that the share of non-specific complaints decreased by $52 \%$, share of those reporting malfunctioning cardiovascular system and respiratory organs - by $46.6 \%$. However, the students complained about problems with musculoskeletal system as often as they used to, since it was the timetable that changed and not the vocational training algorithms.

Analysis of the state anxiety levels revealed they have shifted towards moderate values. Trait anxiety did not change significantly, which reflects peculiarities of personal characters of the students.

Automation of the timetable compilation routine improved its efficiency and clarity through information support; moreover, the software allowed optimization of utilization of the teaching workforce, which is limited.

\section{DISCUSSION}

Examining the conditions $\mathrm{HC}$ adolescents receive vocational education in, we found violations of sanitary and hygienic requirements in individual workplaces. The harmful physical factors peculiar to the workshops students learn the trades in are insufficient artificial lighting and excessive noise; the harmful chemical factors (polluting air in the working zone) are excessive dust content, presence and volume of organic solvents and allergens. Thus, the conditions were deemed hazardous, the labor itself - intense (as described in the labor classification). Our findings are in line with those of other researchers who revealed the discrepancy between the conditions of training and hygienic standards [19]. Moreover, harmful factors of the working environment and labor itself (1-3 degrees) accompany the subsequent employment of students, contributing to the development of occupational pathologies [20].

Comprehensive assessment of the educational process in the vocational boarding school for $\mathrm{HC}$ students revealed that the classes timetable is not rational in terms of duration of various activities and the frequency of their alternation. As a result, adolescents learning both trades researched exhibited: low mental efficiency, low levels of state anxiety (76.2\%), unsatisfactory biological adaptation levels (44.85\%), strain of the adaptation mechanisms (21.2\%). The difference between the sick rates peculiar to second and first half-year periods (based on the registered requests for medical assistance) was statistically significant and equaled 7.08 and 5.23 per 1000 people, respectively $(p<0.01)$.

In the context of the study, we have developed a software program that automates compilation of the classes timetable while factoring in the functional peculiarities of $\mathrm{HC}$ adolescents' body systems. A 6-month trial of the hygienically rational timetable based on the subjects' difficulty scores confirmed its effectiveness. Introduced, the timetable secured a 52\% decrease of non-specific complaints and a $46.6 \%$ decrease of those pertaining to problems with cardiovascular system and respiratory organs. At the same time, the state anxiety levels shifted toward moderate values and the number of students exhibiting average ME grew.

To further combat the adverse effects the factors peculiar to training and production environment have on the adolescents' organisms, the boarding school was given a developed set of guidelines approved by Rospotrebnadzor (Russian Agency for Health and Consumer Rights) in the Saratov region; the guidelines prescribe concrete measures:

- conducting occupation-related classes in rooms the floorspace and volume of which are sufficient for the number of students in a group or making that number smaller;

- installation of a fume hood (for adhesive operations) in the shoe repairs workshop;

- introduction of physical activity breaks, required due to the fact that over $80 \%$ of time at the practical lessons students have to maintain the same pose;

- installation of the local sources of light on the shoe repairman's workbenches and those designed for machine and manual operations part of the sewing machine operator training routines; 
- use of the means of personal protection to counter the adverse effects of excessive noise (earplugs, helmets, headphones), vibration (mittens with inserts, mittens and gloves with reinforced palm covers, gripping pads and plates for vibrating arms and parts);

- control of performance of the ventilation system, its timely sanitary and technical maintenance in the workshops;

- motivating students to lead a healthy lifestyle.

\section{CONCLUSIONS}

The sanitary and hygienic conditions handicapped adolescents receive their vocational education in are suboptimal. Assessing the shoe repairmen training environment, we found that the air of workshops was polluted with chemicals (acetone 4.5 MPC, carbon monoxide - 1.5 MPC), and the sewing equipment operator training implied intense labor (over $40 \%$ of the lesson's time students have to concentrate on a single objects) and noise level 1.6 times the norm. The classes timetable was found to be not rational, which can be another factor adversely affecting adaptation of the handicapped people exercising their right to study and work. Thus, there is a need to optimize the training conditions in vocational schools educating this group of students. Based on the results of the study, we have developed and introduced a software program to automatically compile the school's timetable with the aim to improve psychosomatic health of the students and halve the number of health-related complaints, which translates into better alignment of professional training conditions and requirements imposed by the functional capabilities of people with disabilities.

\section{References}

1. Shubochkina El, Molchanova SS, Ibragimova EM, Kulikova AV. Gigienicheskie i mediko-social'nye problemy podgotovk uchashhihsja v professional'nyh kolledzhah. Gigiena i sanitarija. 2009; 2: 6-29.

2. Istomin AV, Kirjushin VA, Eliseev YuYu, Kleshhina JuV, Tjaptirgirjanova VM. Obzor nauchno-prakticheskih konferencij, posvjashhennyh sovremennym problemam gigieny, profilaktiki ohrany zdorov'ja naselenija za 2012 god. Zdorov'e naselenija i sreda obitanija. 2013; (3): 38-3.

3. Mochalova EK. Kachestvo zhizni podrostkov-invalidov — vazhnaja problema sovremennosti. Voprosy sovremennoj pediatrii. 2006; (5): 396-398.

4. Alaeva NS. Razrabotka tehnologij distancionnogo obuchenija invalidov s deprivaciej sluha. Otkrytoe i distancionnoe obrazovanie. 2008; (3): 21-8.

5. Beljaevskij BV. Problemy trudovogo obuchenija i professional'no podgotovki detej i podrostkov s nedostatkami intellektual'nogo razvitija. Special'noe obrazovanie. 2009; (4): 5-19.

6. Bersenev MV, Musabirov IL. Centr soprovozhdenija studentov s invalidnost'ju kak proektnyj ofis: osnovnye praktiki i rekomendacii. Vestnik Tomskogo gosudarstvennogo universiteta. 2011; (3): 188-91.

7. Kuchma VR. Formirovanie zdorovogo obraza zhizni detej i edinogo profilakticheskogo prostranstva $\vee$ obrazovatel'nyh organizacijah: problemy i puti reshenija. Gigiena i sanitarija. 2015; 94 (6): 20-5.

8. Ibragimova EM. Gigienicheskaja ocenka raznyh form podgotovk podrostkov rabochim professijam $v$ professional'nyh kolledzhah [dissertacija]. M., 2009.

9. Kazaeva OV. Gigienicheskie i mediko-social'nye aspekty professional'nogo obuchenija podrostkov (na primere obrazovatel'nyh uchrezhdenij nachal'nogo professional'nogo obrazovanija mashinostroitel'nogo profilja) [dissertacija]. Rjazan', 2011

\section{Литература}

1. Шубочкина Е. И., Молчанова С. С., Ибрагимова Е. М., Куликова А. В. Гигиенические и медико-социальные проблемы подготовки учащихся в профессиональных колледжах. Гигиена и санитария. 2009; 2: 6-29.

2. Истомин А. В., Кирюшин В. А., Елисеев Ю. Ю., Клещина Ю. В., Тяптиргирянова В. М. Обзор научно-практических конференций, посвященных современным проблемам гигиены, профилактики и охраны здоровья населения за 2012 год. Здоровье населения и среда обитания. 2013; (3): 38-3.

3. Мочалова Е. К. Качество жизни подростков-инвалидов важная проблема современности. Вопросы современной
10. Eliseeva YuV, Dubrovina EA, Eliseev YuYu, Istomin AV. Sostojanie realizacii zdorov'esberegajushhih tehnologij $v$ obrazovatel'nyh uchrezhdenijah. Zdorov'e naselenija i sreda obitanija. 2017; 4 (289): 35-7.

11. Goncharova GA, Nadezhdin DS. Formirovanie social'nopsihologicheskoj adaptacii shkol'nikov i uchashhihsja professional'nyh uchilishh. Gigiena i sanitarija. 2009; (2): 30-3.

12. Kozhevnikova NG. Osobennosti zabolevaemosti studentovpodrostkov v processe adaptacii k obucheniju v vuze. Pediatrija. Zhurnal im. GN Speranskogo. 2012; 91 (5): 142-5.

13. Smirnov NK. Zdorov'esberegajushhie obrazovatel'nye tehnologii v sovremennoj shkole. M.: 2002; $121 \mathrm{~s}$.

14. Nefedov PV, Kutumova NB. Sposob formirovanija ezhednevnoj uchebnoj nagruzki detej-invalidov s narusheniem sluha mladshih starshih klassov. Patent RF \# 2006143491/14. 20.06.2008.

15. Ababkov VA, Bizjuk AP, Volodin NN. Klinicheskaja psihologija. M., 2004; 956 s.

16. Ratanova TA, Shljahta NF. Psihodiagnosticheskie metodiki izuchenija lichnosti. M., 2003; $234 \mathrm{~s}$.

17. Baevskij RM, Laube V, Berseneva AP. Issledovanie mehanizmov vegetativnoj reguljacii krovoobrashhenija na osnove ortostaticheskogo testirovanija $s$ ispol'zovaniem matematicheskogo analiza ritma serdca. Vestnik Udmurtskogo universiteta. Serija Jekonomika i pravo. 1995; (3): 3.

18. Kuindzhi NN. Valeologija: puti formirovanija zdorov'ja shkol'nikov. M., 2001; $136 \mathrm{~s}$.

19. Bubnova EV, Guseva NK. Social'nye aspekty reabilitacii invalidov, poluchajushhih nachal'noe professional'noe obrazovanie na baze Nizhegorodskogo uchilishha-internata dlja invalidov. Medikosocial'naja jekspertiza i reabilitacija. 2008; (1), 12-4.

20. Gindjuk AV. Obosnovanie gigienicheskih trebovanij k uslovijam truda invalidov po sluhu [dissertacija]. Minsk, 2015. педиатрии. 2006; (5): 396-398.

4. Алаева Н. С. Разработка технологий дистанционного обучения инвалидов с депривацией слуха. Открытое и дистанционное образование. 2008; (3): 21-28.

5. Беляевский Б. В. Проблемы трудового обучения и профессиональной подготовки детей и подростков с недостатками интеллектуального развития. Специальное образование. 2009; (4): 5-19.

6. Берсенев М. В., Мусабиров И. Л. Центр сопровождения студентов с инвалидностью как проектный офис: основные практики и рекомендации. Вестник Томского государственного университета. 2011; (3): 188-91. 
7. Кучма В. Р. Формирование здорового образа жизни детей и единого профилактического пространства в образовательных организациях: проблемы и пути решения. Гигиена и санитария. 2015; 94 (6): 20-5.

8. Ибрагимова Е. М. Гигиеническая оценка разных форм подготовки подростков рабочим профессиям в профессиональных колледжах [диссертация]. М., 2009.

9. Казаева О. В. Гигиенические и медико-социальные аспекты профессионального обучения подростков (на примере образовательных учреждений начального профессионального образования машиностроительного профиля) [диссертация]. Рязань, 2011.

10. Елисеева Ю. В., Дубровина Е. А., Елисеев Ю. Ю., Истомин А. В. Состояние реализации здоровьесберегающих технологий в образовательных учреждениях. Здоровье населения и среда обитания. 2017; 4 (289): 35-7.

11. Гончарова Г. А., Надеждин Д. С. Формирование социальнопсихологической адаптации школьников и учащихся профессиональных училищ. Гигиена и санитария. 2009; (2): 30-3.

12. Кожевникова Н. Г. Особенности заболеваемости студентовподростков в процессе адаптации к обучению в вузе. Педиатрия. Журнал им. Г. Н. Сперанского. 2012; 91 (5): 142-5.

13. Смирнов Н. К. Здоровьесберегающие образовательные технологии в современной школе. М., 2002; 121 с.
14. Нефедов П. В., Кутумова Н. Б. Способ формирования ежедневной учебной нагрузки детей-инвалидов с нарушением слуха младших и старших классов. Патент РФ № 2006143491/14. 20.06.2008.

15. Абабков В. А., Бизюк А. П., Володин Н. Н. Клиническая психология. М., 2004; 956 с.

16. Ратанова Т. А., Шляхта Н. Ф. Психодиагностические методики изучения личности. М., 2003; 234 с.

17. Баевский Р. М., Лаубе В., Берсенева А. П. Исследование механизмов вегетативной регуляции кровообращения на основе ортостатического тестирования с использованием математического анализа ритма сердца. Вестник Удмуртского университета. Серия Экономика и право. 1995; (3): 3.

18. Куинджи Н. Н. Валеология: пути формирования здоровья школьников. М., 2001; 136 с.

19. Бубнова Е. В., Гусева Н. К. Социальные аспекты реабилитации инвалидов, получающих начальное профессиональное образование на базе Нижегородского училища-интерната для инвалидов. Медико-социальная экспертиза и реабилитация. 2008; (1); 12-4.

20. Гиндюк А. В. Обоснование гигиенических требований к условиям труда инвалидов по слуху [диссертация]. Минск, 2015. 